\title{
sciendo
}

DOI: 10.2478/orga-2019-0004

\section{Motivation of Knowledge Workers - the Case of Albania}

\author{
Peter NIENTIED ${ }^{1}$, Merita TOSKA ${ }^{2}$ \\ ${ }^{1}$ Polis University, Tirana, Albania, and NCOI University of Applied Arts, Hilversum, The Netherlands \\ nientied1@chello.nl \\ ${ }^{2}$ Co-PLAN Institute for Habitat Development, Tirana, Albania, and Polis University, Tirana, Albania \\ merita_toska@co-plan.org
}

\begin{abstract}
Background and Purpose: Very little is known about motivation of knowledge workers in the Western Balkans. There is a widespread belief that money and career opportunities are the most critical motivational factors, but from a pre-study more intrinsic motivational factors also appeared to be important. To develop a better understanding of work motivation, a study was conducted among knowledge workers in Albania, with a special interest in the themes of extrinsic / extrinsic motivation and organizational commitment.

Methodology: After a pre-study and a review of theory, two motivation theories (self-determination theory and organizational commitment) and corresponding instruments (Work Extrinsic and Intrinsic Motivation Scale, respectively Organizational Commitment Questionnaire) were selected. A survey based on purposive homogeneous sampling was applied, resulting in 252 valid questionnaires. The internal consistency of the survey data was tested and resulted in acceptable to good levels.

Results: The findings show that, when knowledge workers are asked about their motivation, they give answers showing that intrinsic motivational factors are more important than extrinsic motivational factors. The study shows that affective commitment - the core factor of organizational commitment - of the respondents is quite high. Correlation analysis of the data shows that across age, gender and number of years of employment, knowledge workers report intrinsic and introjected motivation and affective organizational commitment. Respondents' work positions - professional or leadership - also do not significantly correlate with motivation and organizational commitment.

Conclusion: Given the results on motivational factors and organizational commitment, organizations need to pay attention to the relationship between enhanced motivation and enhanced productivity. Current transactional leadership styles do stimulate employees on the basis of their intrinsic motivation to enhance their productivity, and should be considered too.
\end{abstract}

Keywords: motivation; self-determination; organizational commitment; Albania; Western Balkans

\section{Introduction}

In a recent review of motivation theory, Kanfer, Frese \& Johnson (2017) state that work motivation is a topic of crucial importance to the success of organizations and societies and the well-being of individuals. A motivated workforce represents both a competitive advantage and a critical strategic asset in any work environment (Tremblay, et al., 2017). Although hard to quantify, academic work and common sense tell us that inadequate attention to 'HRM, management and motivation', leads to far from optimal employee productivity and work values and that good motivation management leads to better performing companies (Boselie, 2014). Many CEE (Central and Eastern European) organizations fail to harvest the benefits of motivation management. Much academic research on work motivation has been carried out in the West, but the subject of motivation, and HRM in general, is under-researched in CEE (cf. Hernaus and Mikulić, 2013; Poór, et al., 2015). This is especially true for the Western Balkan (WB) countries; studies on HRM and topics such as moti-

Received: September 3, 2018; revised: November 4, 2018; accepted: January 30, 2019 
vation, are rather occasional (Nientied and Shutina, 2017).

After the change of systems during the early 1990's, attention was focused on building institutions, transforming companies and attracting foreign investments. But over 25 years after the change of system, the field of HRM and motivation is still rather out of favour in CEE, both in organizations and research. As an explanation for the scarcity of research on HRM and motivation in CEE, Zientara (2014) argued that the limited attention to HRM in higher education (and subsequently in practice) can be seen as part of the legacy of the past.

The present study on work motivation and management aims to contribute to a better understanding of HRM in WB countries. In 2017, a study was conducted on high performance work practices in Albania, examining to what extent Albanian organisations apply elements of the AMO model (Abilities, Motivation and Opportunities) in their strategic HRM (Nientied and Shutina, 2017). The study revealed that HRM is often limited to basic personnel administration, that in many organisations HRM is viewed as a cost item - not as investing in people to enhance productivity. HRM is task-oriented, not people-oriented. In larger companies, especially subsidiaries of international companies, HRM is better developed albeit that variation was noted. Numerous managers were asked why HRM does not receive more attention. Reflecting on the answers received, it was concluded that the task orientation and mindset of management play an important role. In Albania and its surrounding countries, pay, career opportunities and respect for the labour code are believed to be important factors that influence work motivation. But in the preparatory interviews for the present study, points such as pride of work, identification with work, achievement in professional life and commitment to the organisation were also mentioned. These answers and further observations gave impressions on work motivation and, given the lack of data and understanding of work motivation in Albania, instigated us to carry out research on work motivation and organisational commitment.

The field of work motivation studies in Albania is still undeveloped. Shoray and Llaci (2015) discuss job satisfaction in the second-level bank system in Tirana, Zhilla (2013) applied the Job Diagnostic Survey among university staff, and Suma and Lesha (2013) discussed job satisfaction and organizational commitment in a municipal organization. Apart from these studies (that deal with job satisfaction rather than motivation), no published research on employee motivation in Albania was found. For other WB countries, also very few studies could be discovered. In CEE countries outside the WB, studies have been carried out. For example, Damij (et al., 2015) found that Slovenian knowledge workers are stimulated by a series of factors like relationships with superiors and colleagues, sense of achievement, helpful colleagues, personal growth, largely in contrast to the traditional understanding that mainly emphasizes money and prestige as motivation factors.
Hajdukova, Klementova \& Klementova (2015) examined a range of satisfaction factors in their study in Slovakia. Jordan et al., (2017) included three CEE countries in their study on job satisfaction and organizational commitment in higher education organizations. Of course, Albania is quite different from Slovenia or Slovakia, but personal work motivation factors do not need to be. Therefore, the plan was to conduct a survey on motivation and organizational commitment, identify socio-economic forces in the context, and try to discover possible patterns and correlations with personal and organizational characteristics. The focus of the research is on Albania. Obviously, this signifies a limitation - a comparison with other Western Balkan countries would be interesting, but also requires a research collaboration in WB countries and research funding. This was not available for this study.

The definition of work motivation of Kanfer (1990) was used as point of departure: "the psychological processes that determine (or energize) the direction, intensity, and persistence of action within the continuing stream of experiences that characterize the person in relation to his or her work." The present study focuses on knowledge workers, a notion lacking a clear definition. It is taken in a broad meaning as workers whose main capital is knowledge and information processing, and work with $21^{\text {st }}$ century skills such as critical thinking, problem solving, research, creativity, communication, and ITC literacy. The focus on knowledge workers implies a limitation, but the choice was deliberate for two reasons. First, this segment of workers adds high values to companies and is therefore a prime target group for management in companies wanting to increase productivity and commitment. Second, also in WB countries' economies, the future of jobs is not in production and low-skilled or middle-skilled level labour, but in the knowledge and creative sectors (WEF, 2016; Nientied and Karafili, 2016; Lewandowski, 2017) as popular authors such as Pink (2011) and Hamel (2012) argued before. Morgan (2014) identifies five trends that shape the future of work: new behaviours fashioned by social media and the web, technologies, the millennial workforce with new attitudes and expectations, mobility regarding place of work and globalization. Morgan (2014) asserts that this requires new relationships between management and employees, and that managers should take up roles of transformational leaders. This should also be relevant to companies in the $\mathrm{WB}$, for this the segment of knowledge workers cannot just be managed in a transactional manner if a company wants to keep up motivation levels.

The following two research questions were formulated to guide the empirical research: - which are personal motivation factors (extrinsic / intrinsic) of Albanian knowledge workers, 'why do they go to work'?; and, 2) do Albanian knowledge workers feel committed to their work organization?

In the next chapter, theory of motivation will be briefly reviewed. Textbooks give good overviews of different 
motivation theories (e.g. Kanfer et al., 2008a), that need not be repeated. The theoretical focus of this study is on the models selected for the present study. In chapter 3 the methodology of the study will be explained, before attention will turn to the results of the research in chapter 4 , consisting of a context description and a presentation and analysis of the survey results. In the final chapter, the main findings of the study are discussed and recommendations for further research and for organizational practice are submitted.

\section{Review of theory}

Mullins (2010) made a three-fold classification for the study of motivation to work. He distinguishes: i) an instrumental orientation looking at economic rewards etc., ii) a personal orientation looking at the intrinsic satisfaction derived from the work itself and personal growth, and iii) a relational orientation, with a focus on social relationships. Kanfer, Chen and Pritchard (2008b) have organized motivation studies along 3 C's: content, context and change. There are many competing theories attempting to explain the nature of motivation (Mullins, 2010, 259). They all help to try and clarify the behaviour of certain people at certain times. Mullins (2010) adds that age plays a role: younger people in their first job have different needs than people at mid-career or late career positions who have limited opportunities for further advancement. However, Kooij (et al., 2011) found that age-related differences in work motivation is a quite complex question. Mullins (2010) also wondered what the relationship is between job satisfaction and motivation and performance. There are many more questions about and debates around motivation theory, including the validity of motivation concepts across cultures, measurement issues of motivation (Ployhart, 2008), whether intrinsic motivation can be distinguished in practice from extrinsic motivation, the relationship between motivation and organisational commitment, etc. (Latham, 2012). The difference between motivation as intention and actual behaviour in the organisation should also be mentioned. That is even more so in job satisfaction research: the concept of job satisfaction assumes that satisfied employees perform better. This, however, is not always the case; practices vary. People may be satisfied with their job because the hours are good, or they can lead an easy life. ${ }^{1}$ In their meta-review of motivation theories, Kanfer, Frese \& Johnson (2017) mention the research - practice gap: given the diverse field of motivation studies and the various approaches, leadership in organizations cannot be well informed about management of motivation and tend to 'pick and choose' a model based on ad-hoc considera- tions. Meanwhile, motivation theory tends to develop new concepts such as engagement and organizational citizenship behaviour (OCB) and employee trust (Boselie, 2014).

Kanfer, Frese \& Johnson (2017) distinguish three types of content-oriented motivation theories; universal motives (needs as internal forces), intrinsic motivation and justice motives. Intrinsic motivation theory (self-determination theory) redresses some shortcomings of need theories, the latter identify needs but do not predict behaviour, whereas self-determination theory does through intrinsic motivation. Justice motives address the desire for fairness and are less relevant for the present study. Regarding organizational commitment, Mercurio (2015) concludes that scholars studying commitment still have not come to an agreement as to the nature of organizational commitment and how it develops, but affective commitment - the emotional attachment of an individual to the organization - seems to be at the core of organizational commitment. Therefore, a widely used model for organizational commitment was selected, as will be explained below. For the present research on Albania, it was opted for two content-based approaches to motivation: the self-determination theory and the model of organizational commitment.

Self-determination theory (SDT) focuses on the "why of behaviour' (Deci and Ryan, 2000, 229; Ryan and Deci, 2000). SDT maintains that all human beings have three basic psychological needs that must be satisfied for them to function optimally. They are the needs for competence or effectance, relatedness or belongingness, and autonomy or self-determination, which are essential for psychological health and well-being and facilitate effective functioning in social setting (Deci, Olafsen \& Ryan, 2017). This basic-needs proposition was not formulated from clinical observations or philosophical assumptions, but was formulated empirically while studying the conditions under which people tend to thrive (Deci and Ryan, 2012). The basic premise of SDT is that people are intrinsically willing to integrate themselves in the environment and to grow. The (social) environment of a person influences this tendency to personal growth and integration. SDT makes a distinction between intrinsic motivation (doing activities for their own sake because one finds the activity inherently interesting and satisfying) and extrinsic motivation (i.e., doing an activity for an instrumental reason, like getting a monetary or personal reward). Evidence shows, explains Pink (2011), that for mechanical jobs, extrinsic motivation works (e.g. more pay for more work), that for work with a cognitive element, intrinsic motivation is required. Extrinsic rewards for most intrinsically motivated people in jobs even have an adverse effect, if basic labour conditions are not an issue any more (e.g. salaries are in accordance with

1 Some companies have an 'employee first' policy, with a basic premise that contented or happy employees perform better. South West Airlines is a well-known example. In such companies, serious demands are made on employees and strict selection procedures are in place, and teams are responsible for performance. It is far from a free-floating culture. 
Behaviour

Motivation

\section{Type of} regulation

Sources of regulation
Least self determined
Most selfdetermined

Intrinsic motivation motivation motivation

$\begin{array}{cc}\text { External } & \text { Introjected } \\ \text { regulation } & \text { regulation }\end{array}$

$$
\begin{gathered}
\text { Identified } \\
\text { regulation } \\
\text { Importance } \\
\text { of goals }
\end{gathered}
$$

\section{Importance of goals}$$
\text { Integrated }
$$$$
\text { regulation }
$$$$
\text { Approval from }
$$$$
\text { reward }
$$$$
\text { punishment }
$$
Personal meaningfulness of goals

\author{
Intrinsic \\ regulation \\ Interest, \\ satisfaction, \\ joy
}

Figure 1: Self-Determination Continuum

Source: Authors, based on Deci and Ryan (2000), Ryan and Deci (2000), Clayton (2015).

market levels). This is not a law: some top managers are highly rewarded and still want to receive an even higher reward. And some low-paid workers in, say, routine agricultural work, take pride in their work and enjoy it. SDT has created a continuum from 'a-motivation' (passiveness, lack of intention) to purely intrinsic motivation. Figure 1 illustrates the types of motivation, arranged from left to right in terms of the extent to which the motivation for one's behaviour emanates from one's self.

Intrinsic motivation is defined as the doing of an activity for its inherent satisfactions rather than for some separable consequence like a bonus. When intrinsically motivated, a person is moved to act for the fun or challenge entailed rather than because of external pressures or rewards. Extrinsic motivation is defined as the doing of an activity in order to attain some separable outcome. Extrinsic motivation thus contrasts with intrinsic motivation, which refers to doing an activity simply for the enjoyment of the activity itself, rather than its instrumental value. SDT proposes that extrinsic motivation can vary greatly in the degree to which it is autonomous (Ryan and Deci, 2000). Externally regulated behaviours are performed to satisfy an external demand or obtain an externally imposed reward. Introjected regulation describes a type of internal regulation that is still quite controlling, because people perform such actions with the feeling of pressure in order to avoid guilt or anxiety or to attain ego-enhancements or pride. A more autonomous, or self-determined, form of extrinsic motivation is regulation through identification, when a person has identified with the personal importance of a behaviour and has thus accepted its regulation as his or her own (e.g. behaviour compliant with safety regulations, because a person acknowledges that this is a right way of working). The most autonomous form of extrinsic motivation is integrated regulation, that occurs when identified regulations have been fully assimilated to the self, through self-examination and bringing new regulations into congruence with one's other values and needs. Ryan and Deci (2000) pose that intrinsic motivation leads to optimal func- tioning - if personal motivation and the job are aligned. External regulation leads to negative outcomes (unless workers have no free will). SDT is not a developmental scale or ladder in the sense that individuals progress along it in specific stages. New behaviour may be internalised at any point along the continuum depending on factors such as organisational context and an individual's prior experiences. And due to changing circumstances in personal life, employees may lose (or gain) work motivation.

The second model selected is the model of organizational commitment. This is employees' state of being committed to assist in the achievement of the organization's goals, and involves the employees' levels of identification, involvement, and loyalty. Mayer and Allen (1997) state that commitment is experienced by the employee as three simultaneous mindsets encompassing affective, normative, and continuance organizational commitment, and are predictors of performance, absenteeism and organizational citizenship. Affective commitment reflects commitment based on emotional ties the employee develops with the organization primarily via positive work experiences. Normative commitment reflects commitment based on perceived obligation towards the organization, for example rooted in the norms of reciprocity. Continuance commitment reflects commitment based on the perceived costs, both economic and social, of leaving the organization (Jaros, 2007). Starnes and Truhon (n.d.) summarized a number of studies that made correlations between organisational commitment and items such as age, sex and other personal characteristics, job attitudes, job characteristics and relationships with co-workers and supervisors. Solinger, Van Olffen \& Roe (2008) criticize the conceptual side of the organizational commitment model and argue that general organizational commitment can best be understood as an attitude regarding the organization, while normative and continuance commitment are attitudes regarding specific forms of behaviour (i.e., staying or leaving). They suggest that the three-component model of organizational commitment fails to qualify as general model of organizational 
commitment, but instead represents a specific model for predicting turnover. In other words, affective, normative, and continuance commitment cannot be considered as components of the same attitudinal phenomenon (cf. Mercurio, 2015). This study opted for employing the organizational commitment model but will not consider the three components together as organizational commitment. The components are treated individually and be called factors instead of components.

\section{Methodology}

First, a pre-study consisting of interviews and a literature search on motivation in CEE and the WB was conducted. 16 mid-career professionals (knowledge workers) were interviewed with the help of a short item list, pertaining to motivation, job satisfaction, career ambitions, organizational commitment and ideas or plans to work abroad. These interviews revealed that motivation is multi-faceted, that professionals feel (emotional) commitment to their organisation such as pride and relatedness, and that professionals would wish for higher pay but acknowledge that 'the market is as it is', as one of the respondents described the situation. After the literature study, a choice was made to apply SDT and OCQ (organizational commitment questionnaire). From the review of theory, it became clear that a proper contextualization regarding socio-economic forces is useful to better understand work motivation.

Regarding SDT, the scale developed by Tremblay (et al.. 2009) was selected, covering factors from a-motivation at one end of the scale, to intrinsic motivation at the other end of the scale, as Figure 1 showed. This instrument (Work Extrinsic and Intrinsic Motivation Scale - WEIMS) is an 18-item measure of work motivation and suitable to be applied in different work environments. Interesting to add is that Deci (et al., 2001) compared motivational processes in American and Bulgarian organizations and found that their SDT model was applicable across cultures. Gagné (et al., 2014) found evidence that the SDT functions well in seven languages. The starting question of WEIMS is 'why do you do your work'. In Annex 1 the questionnaire with 18 item list is presented, and comparing it with the original (Tremblay et al., 2009, 226), slight adaptations to the Albanian context can be found to enhance user validity.

A set of questions based on the OCQ was added, measuring the factors of affective, continuance and normative commitment, based on Meyer and Allen (1997), and improved by Jaros (2007). Jaros' questionnaire was made more concise after a first field testing. For example, the statement "I do not think that wanting to be a "company man" or "company woman" is sensible anymore." (original Q.8 Normative Commitment) was skipped because these terms are not understood in Albania. 12 accessible statements were selected - four per category - and tested in the field, with a satisfactory result. Reduction of the number of questions was also vindicated by the Kanning and Hills's handling of the OCQ, who use 15 items. In the present survey, an additional open question asks for possible actions the respondents' companies could undertake to enhance work motivation and commitment. The selection of items and metric information of questionnaires are presented in chapter 4 (tables 2 and 3 ).

The questionnaire was filled out by professional specialists and managers employed in organizations with $>$ 10 employees. They are working in various sectors, from services such as banking, tourism and retail, to sectors like energy and medical, and have roles as specialists in their field, as project manager or team leader / manager. Questionnaires have not been sent out via e-mail because that leads in our experience to rather substandard quality of information in Albania. Respondents are very cautious with regards to anonymity and they tend to give affirmative answers to questionnaires sent by mail. Moreover, non-response tends to be high. Albania is a low-trust society, an attribute rooted in the country's past. Distributing questionnaires through a network (of trusted people) and in hard-copy gives much better results. Therefore, purposive homogeneous sampling was applied. First, the draft questionnaire was discussed with professionals in the field (an expert panel was not possible because Albania has no academic experts in HRM and motivation studies), then tested among a restricted number of observations and no major problems were found except for the need to rephrase some OCQ items. Then, after a briefing of the objective and the implementation of the study, questionnaire forms were given to post-graduate students studying in Polis University's executive MBA, to staff members working in Polis University and in Co-PLAN Institute for Habitat Development in a first stage. They were asked to fill out the questionnaire themselves and in the second stage to give questionnaires to people in their network, have the questionnaires filled out and have a discussion with the respondents about their scores, to check whether they had understood everything and to discuss about the final open-ended question (that also functioned as an overall check on the answers given). Post graduate students and employees of Polis and Co-PLAN are typically in the age category of 28 to 40 years, have positions with professional or managerial responsibilities, and jobs that can be classified as knowledge worker. The survey sample is not representative for the whole Albanian work force and not even for the segment of knowledge workers in the country. Most of the interviewers (MBA students and Polis - CoPLAN staff) live in the Tirana - Durres region which is the economically most advanced region of Albania. They have approached respondents from organizations in their region and therefore, the survey conducted has a bias towards this region and to more modern and larger organizations. The government sector was excluded intentionally (motivation and commitment have different characteristics), while 
semi-public companies and not for profit institutions, were included. The survey part was conducted during January - February 2018 while the (statistical) analysis was done in March - April 2018. In total, 252 valid questionnaires were processed. With regards to validity and reliability of the study, two limitations mentioned are: - the sample has an unknown bias and is not representative for the country, or for the category knowledge workers in general; - validated questionnaires have been slightly adapted to fit the Albanian context. Despite these two limitations, the faceto-face interviews to fill the questionnaires ensure that the quality of information gathered is much higher than in an on-line survey in the Albanian context. Also, as a first motivation survey, the sample serves the goal of the study.

\section{Results}

\subsection{The context}

In Albania there are some common features that might affect motivation, broadly driven by historical similarities. For the purpose of this study, first socio-cultural forces are sketched. They may be more universal for the CEE; Holden and Vlaiman (2013) -distinguish comparable forces in their contextualization of HRM and talent management in Russia. Each of the points mentioned would warrant a fuller elaboration, but that would be beyond the scope of this paper. For the contextualization of this study, some important trends in Albanian society are the following:

Slowly picking up economy, more exposure to globalization

Unlike more developed former socialist countries now in the EU, Albania and its neighbours experienced a limited modernisation of higher education, inflow of international companies, and EU support and influences. As a small, formerly isolated country, Albania still has a rather backward economy with limited export capacities. The domestic nature of competition was identified by Prašnikar (et al., 2012) as a main factor in this regard. The external trade balance of Albania remains unfavourable: in 2017 it was $-15.1 \%$ of GDP (World Bank, 2018). Innovation in Albania is still at an early stage of development (Nientied and Karafili, 2016; Matusiak and Kleibrink, 2018). Albania is now connected to the world through the web, and Albanians travel and study abroad - they tend to become dissatisfied with the general economic and business climate in Albania.

High un(der)employment, exit of knowledge workers Unemployment decreases but remains high; the unem- ployment rate in 2017 was $13.8 \%$ and the youth unemployment rate was in 2017 25.9\% (World Bank, 2018). In view of the perceptions of a lack of jobs in Albania, many Albanian young people, given a chance and irrespective of educational level, would opt for a job abroad (RCC, 2017), as many already did (Vracic, 2018). In Albania, high un(der)employment has many implications: people accept jobs way below their educational level, ${ }^{2}$ they can be replaced easily when they request higher payment, trainings or other fringe benefits. These labour market dynamics have shaped firms' behavioural attitudes (cf. Nientied and Shutina, 2017).

\section{The tradition of bossdom and mistrust}

Albania management is broadly traditional and masculine. In the Russian case, Holden and Vlaiman $(2012,136)$ use the phrase 'entrenched bossdom', which is a brand of management that somehow combines authoritarian sternness with paternalism, frenzied networking with isolation of those at the top who decide everything independently from the workfloor. This is relevant (and not unique to Russia). They quote an article from the Economist, that speaks of "The long life of homo Sovieticus" referring to "mental software', and it is the persistence of the coercion and brutishness that came with Soviet totalitarianism rather than a deep yearning for the good old days of central planning and communism. In Albania, this culture is rooted too and still present in its own fashion. In a society with low trust levels, traditional bossdom in many organizations and high unemployment, organizational commitment may have a special character.

\section{Old and new co-exist}

Albania has good examples of modern HRM, practices comparable to modern organisations in the EU, where managers pay attention to their employees and employee productivity. They can be found in subsidiaries of international organisations wanting to have the best people in the market, in modern Albanian organisations, especially those who need people and skills that are not readily available (like IT specialists, creative designers and social media specialists, certain academicians, etc.) and in Albanian organizations with modern leadership and people-centred values. But traditional HRM practices are widely found - HRM limited to personnel administration, with 'bosses' selecting staff in a paternalistic / political rather than a merit-based manner - and transactional leadership styles.

2 See http://www.balkaninsight.com/en/article/diploma-factories-kosovo-and-albania-churn-out-graduates-with-few-prospects-11-08-2015-1 


\subsection{Survey results}

\section{Respondents}

The sample was composed of $\mathrm{N}=252$ observations, out of which 163 were women and 89 were men. The age distribution of the respondents is given in table 1. Respondents' age varies from a minimum of 19 years old to a maximum age of 60 years old, with an average age of 31.1 years.

Table 1: Age respondents $(n=252)$

\begin{tabular}{|c|c|}
\hline Age group & $\mathbf{\%}$ \\
\hline $18-29$ years & $50.3 \%$ \\
\hline $30-40$ years & $38.8 \%$ \\
\hline 41 years and older & $10.8 \%$ \\
\hline
\end{tabular}

Based on the gender composition and age group distribution of observations, the sample presents an unknown bias towards women and towards younger age categories. Since the total number of knowledge workers is not known, it is difficult to specify exactly the nature of this bias. The sectoral composition of the sample shows that $79.4 \%$ of the respondents working in the private for-profit sector, $13.9 \%$ in private not for profit and only $6.7 \%$ of the observations in the semi-public sector. About $35.7 \%$ of the respondents in the sample has a leadership role within the organization while the rest are knowledge workers without leadership role.

Tables 2 and 3 present the descriptive statistics of the questionnaire statements of the WEIMS part and the OCQ part respectively.

The internal consistency of the survey data was tested using Cronbach's alpha. This test was applied for each set of variables explaining the 6 types of regulation of the WEIMS self-determination continuum and the 3 factors of commitment; affective, continuance and normative commitment. The internal consistency results are at good levels ( $>0.7)$ for integrated and introjected regulation and a-motivation, while close to a lower acceptable level in the case of intrinsic, identified and external regulation. Table 5 below shows that the factors of affective, continuance and normative commitment, indicated adequate levels.

In Table 6, the questions have been assembled to WEIMS factors, and the descriptive statistics of the WEIMS factors are presented.

From the results of the survey it was found that motivation is more towards the intrinsic side than conventional understanding suggests - when knowledge workers are asked questions about their motivation, they give answers that show that intrinsic motivational factors are more important than extrinsic motivational factors. In the open question of the survey questionnaire, payment was mentioned quite frequently as a stimulus of motivation, articulated in different terms like bonuses, higher salaries, performance-based payment schemes etc. Alongside monetary rewards, other non-monetary aspects mentioned to enhance motivation include - educational and other personal development opportunities, - carrier paths within the organization, - participation in decision making, etc.

Regarding the organizational commitment factors (table 7), it turns out that the affective commitment - the core factor of organizational commitment - of the respondents is quite high. This shows that knowledge workers don't just go to work to produce, but also because it gives them a sense of belonging, membership and pride. Continuance commitment and normative commitment are also positive but have lower average scores and higher standard deviations. This suggests that a positive attitude (affective commitment) toward the job does not mean that employees stop looking for better opportunities. It is, as will be shown later in table 8 , only weakly related to age. This can be understood in the context of the Albanian employment market, with mostly temporary contracts that are to be renewed every year. People may work many years for their organizations, but most of them lack job security.

A correlation analysis (Table 8) shows that correlations between motivational and commitment factors and characteristics as gender, age and number of years in the present organization are limited.

With age, external regulation and integrated regulation correlation tend to go up a bit, but correlations are low. Continuance commitment correlates positively but not strongly, with age and number of years in the present organization, and this is line with expectations. With regards to position in the organisation, whether or not the respondent had a leadership position, correlations hardly differ between employees with and without a leadership position. Respondents with a leadership position scored a bit lower (but significant at 0.05 level) on the factors of intrinsic motivation and identified motivation. Overall, it is interesting to see that correlations between factors of motivation and commitment on the one hand, and characteristics of age, number of years in the organization and gender, are low. The finding of age-related to motivation, confirms the observations of Kooij (et al., 2011) that age-related differences in work motivation is a complex question - among Albanian knowledge workers age does not play a significant role.

\section{Discussion and conclusions}

This research found that motivation is much more towards the intrinsic side of the extrinsic - intrinsic continuum than conventional perceptions suggest. When questions are asked about motivational details, extrinsic motivation (money and prestige) is not the most important motivational factor (when regular market salaries are paid). In the 
Table 2: Descriptive statistics responses WEIMS

Scale: 1 = don't agree at all, $4=$ neither agree or disagree, $7=$ agree completely. $n=252$.

\begin{tabular}{|c|c|c|}
\hline Statement 'Why do you go to work' (WEIMS) & Ave. & St.dev. \\
\hline Q1: Because I chose this type of work to attain my career goals & 5.27 & 1.76 \\
\hline Q2: For the income it provides me & 5.18 & 1.42 \\
\hline $\begin{array}{l}\text { Q3: I don't know why I still do this job, I don't seem to be able to manage the important tasks of } \\
\text { the job }\end{array}$ & 1.54 & 1.21 \\
\hline Q4: Because I derive much pleasure from learning new things & 5.58 & 1.36 \\
\hline Q5: Because my work has become a fundamental part of who I am & 4.96 & 1.71 \\
\hline Q6: Because I want to succeed at this job - if not, I would be very ashamed of myself & 4.08 & 2.08 \\
\hline Q7: Because this is the type of work I chose to attain a certain lifestyle & 4.66 & 1.72 \\
\hline Q8: For the satisfaction I experience from taking on interesting challenges & 5.55 & 1.41 \\
\hline Q9: Because it allows me to earn money & 5.01 & 1.51 \\
\hline Q10: Because it is part of the way in which I have chosen to live my life & 4.79 & 1.72 \\
\hline Q11: Because I want to be very good at this work, otherwise I would be very disappointed & 4.45 & 2.06 \\
\hline Q12: I don't know why I still do this work, we have very unrealistic working conditions & 1.65 & 1.27 \\
\hline Q13: Because I want to be a 'winner' in life & 4.93 & 1.80 \\
\hline Q14: Because it is the type of work I have chosen to attain certain important objectives & 5.26 & 1.53 \\
\hline Q15: For the satisfaction I experience when I am successful at doing difficult tasks & 5.43 & 1.46 \\
\hline Q16: Because this type of work provides me with security & 4.65 & 1.69 \\
\hline Q17: I don't know why I still do this work, too much is expected of us & 1.98 & 1.62 \\
\hline Q18: Because this job is a part of my life & 4.93 & 1.76 \\
\hline
\end{tabular}

Table 3: Descriptive statistics motivation and commitment statements

Scale: 1 = don't agree at all, $4=$ neither agree or disagree, $7=$ agree completely. $n=252$.

\begin{tabular}{|c|c|c|}
\hline Statement & Ave. & Std.dev. \\
\hline Q1 I feel a strong sense of belonging to this organization & 5.28 & 1.593 \\
\hline Q2 If I wasn't a member of this organization, I would be sad because my life would be disrupted & 2.52 & 1.806 \\
\hline Q3 I feel I would be letting my co-workers down if I wasn't a member of this organization & 2.90 & 1.824 \\
\hline Q4 I am very happy being a member of this organization & 5.68 & 1.404 \\
\hline $\begin{array}{l}\text { Q5 I am loyal to this organization because I have invested a lot in it, emotionally, socially, and } \\
\text { economically. }\end{array}$ & 5.37 & 1.709 \\
\hline Q6 I feel that I owe this organization quite a bit because of what it has done for me & 4.36 & 1.815 \\
\hline Q7 I feel like "part of the family" in my organization & 5.23 & 1.694 \\
\hline Q8 I am dedicated to this organization because I fear what I have to lose in it. & 3.17 & 1.765 \\
\hline Q9 I would feel guilty if I 1 would leave my organization now & 4.15 & 2.035 \\
\hline Q10 It makes me proud to be an employee of this organization & 5.63 & 1.492 \\
\hline Q11 I feel that it is more difficult leaving this organization over time & 4.73 & 1.766 \\
\hline Q12 My organization deserves my loyalty because of its treatment towards me & 5.29 & 1.683 \\
\hline
\end{tabular}


Table 4: Cronbach's alpha's WEIMS factors $(n=252)$

\begin{tabular}{|c|c|c|}
\hline & Questions & Cronbach's alpha \\
\hline Intrinsic motivation & Q4, Q8, Q15 & 0.669 \\
\hline Identified regulation & Q1, Q7, Q14 & 0.696 \\
\hline External regulation & Q2, Q9, Q16 & 0.612 \\
\hline Integrated regulation & Q5, Q10, Q18 & 0.747 \\
\hline Introjected regulation & Q6, Q11, Q13 & 0.789 \\
\hline A-motivation & Q3, Q12, Q17 & 0.740 \\
\hline
\end{tabular}

Table 5: Cronbach alpha's Commitment Organizational commitment factors $(n=252)$

\begin{tabular}{|c|c|c|}
\hline & Questions & Cronbach's alpha \\
\hline Affective commitment & Q1, Q4, Q7, Q10 & 0.852 \\
\hline Continuance commitment & Q2, Q5, Q8, Q11 & 0.686 \\
\hline Normative commitment & Q3, Q6, Q9, Q12 & 0.706 \\
\hline
\end{tabular}

Table 6: Descriptive statistics WEIMS factors (7 point Likert scale) ( $n=252)$

\begin{tabular}{|l|c|c|c|}
\hline & Questions & Average & Std.dev. \\
\hline Intrinsic motivation & Q4, Q8, Q15 & 5.52 & 1.41 \\
\hline Identified regulation & Q1, Q7, Q14 & 5.06 & 1.67 \\
\hline External regulation & Q2, Q9, Q16 & 4.95 & 1.54 \\
\hline Integrated regulation & Q5, Q10, Q18 & 4.89 & 1.73 \\
\hline Introjected regulation & Q6, Q11, Q13 & 4.48 & 1.98 \\
\hline A-motivation & Q3, Q12, Q17 & 1.72 & 1.37 \\
\hline
\end{tabular}

Table 7: Organizational commitment factors (7 point Likert scale) $(n=252)$

\begin{tabular}{|c|c|c|c|}
\hline & Questions & Average & Std.dev. \\
\hline Affective commitment & Q1, Q4, Q7, Q10 & 5.45 & 1.55 \\
\hline Continuance commitment & Q2, Q5, Q8, Q11 & 3.95 & 1.76 \\
\hline Normative commitment & Q3, Q6, Q9, Q12 & 4.18 & 1.84 \\
\hline
\end{tabular}

open questions, payment was mentioned quite frequently as a motivational instrument, but so were educational and other personal development opportunities. The interpretation of the survey results showed that across age, gender and number of years of employment, knowledge workers in Albania report intrinsic motivation to go to work - intrinsic and introjected motivation and affective commitment. The results are in line with the findings of Damij et al. (2015).

Looking at the survey results and the contextualization given in section 4.1, the level of intrinsic / identified motivation and commitment to the organization was perhaps higher than expected based on conventional wisdom, but it was in line with the impressions of the pre-study. Whether employees tend to adjust to the organizational reality and try to make the best of it (and show more intrinsic motivation) cannot be explained by this study - this would require in-depth qualitative research. From the interviews during the pre-study, the impressions of the researchers were that knowledge workers know well whether their salary is in accordance with salary levels in the labour market, and they accept this reality (or search for another job that pays better). Work abroad is an appealing option for many, but this cannot be ascribed to salary levels only. Many educated people in Albania are disappointed with the political climate, corruption and issues of rule of law and take the future for their children into consideration, not just the salary levels. 
Table 8: Pearson correlations

** Significant at 0.01 level, * Significant at 0.05 level. $n=252$.

\begin{tabular}{|l|c|c|c|}
\hline & Gender & Age & No. of years in present organization \\
\hline Gender & 1 & & \\
\hline Age & 0.008 & 1 & 1 \\
\hline No of years in organization & 0.007 & $0.575^{* *}$ & -0.093 \\
\hline Intrinsic motivation & $0.181^{*}$ & -.022 & 0.012 \\
\hline Identified regulation & 0.084 & 0.137 & 0.180 \\
\hline External regulation & 0.162 & $0.211^{* *}$ & 0.138 \\
\hline Integrated regulation & 0.107 & $0.212^{* *}$ & -0.004 \\
\hline Introjected regulation & 0.067 & 0.024 & 0.055 \\
\hline A-motivation & -0.121 & 0.044 & 0.068 \\
\hline Affective commitment & 0.092 & 0.024 & $0.222^{* *}$ \\
\hline Continuance commitment & 0.104 & $0.204 * *$ & 0.094 \\
\hline Normative commitment & 0.056 & 0.147 & \\
\hline
\end{tabular}

This study on work motivation calls for further research. A relevant point for study is the correlation between satisfaction of payment and types of motivation - in this study the sensitive question of satisfaction with salary was not included. This question is difficult to uncover in a reliable manner in a questionnaire-based survey. A second follow up research could focus on the relationship between motivation, work autonomy and performance, to study whether the statement holds that if one has autonomy, and the results then depend more on one's own efforts and the individual feels more personal responsibility for performance, one is motivated to perform better. Various theoretical models could be used for such study. A third option concerns other target groups of the working population. In the introduction, it was argued that knowledge workers add high value to companies and this segment is therefore a prime target group for management in companies wanting to increase productivity and commitment. As the economy modernizes and digitalisation and automation increase, the percentage of knowledge workers will further increase, as WEF (2016) and Schwab (2018) have argued. Yet, motivation among employees who are not typical knowledge workers is important too. Finally, this study was focused on the Albanian situation, and a comparison with other WB countries would be interesting.

For organisational practice it will be advantageous to popularize the topic of motivation and role of leaders / managers in fostering motivation. Two points are particularly relevant; the first is that leaders should be interested in the relationship between enhanced motivation and enhanced productivity - whether enhancing motivation is likely to pay off and what the implications could be for leadership styles. The second is that the so-called $21^{\text {st }}$ century skills become increasingly important and are considered to spearhead the economic future of countries like
Albania (cf. WEF, 2016). Leaders and employees could invest in developing these skills. This also requires new educational solutions from universities and other higher education institutes.

In more general theories of work motivation, the effects of leaders on work motivation have been at the heart of many leadership theories and models, but leadership itself is left out (Zaccaro et al., 2008). In the dynamic relationship manager - employee exchange, leadership develops into a transactional process - employees are not stimulated on the basis of their intrinsic motivation. In such relationship with an autocratic leadership style, employees will adjust their behaviour, and tend to show motivation when the manager is around (Zaccaro et al., 2008). The findings of Damij et al. (2015) on the creation of working conditions that foster good relations with colleagues and superiors, opportunities for personal growth, and good organization within the organization, should be incorporated into the study design too. Such leadership studies are, to our knowledge, absent in the Western Balkans.

\section{Literature}

Boselie, P. (2014). Strategic human resource management - a balanced approach. Maidenhead Berkshire: McGraw Hill.

Clayton, B.C. (2015). Shared vision and autonomous motivation vs. financial incentives driving success in corporate acquisitions. Frontiers in Psychology, 5. 6 January 2015 , http://doi.org/10.3389/fpsyg.2014.01466

Damij, N., Levnajić Z., Rejec Skrt, V., \& Suklan, J. (2015). What motivates us for work? Intricate web of factors beyond money and prestige. PLoS ONE, 10(7), http:// doi.org/10.1371/journal.pone.0132641 
Deci, E.L., Olafsen, A.H., \& Ryan, R.M. (2017). Self-Determination Theory in work organizations: the state of a science. Annual Review of Organization and Psychological Behavior, 4, 19-43, http://doi.org/10.1146/ annurev-orgpsych-032516-113108

Deci, E.L., \& Ryan, R.M. (2012). Self-determination theory in health care and its relations to motivational interviewing: a few comments. International Journal of Behavioural Nutrition and Physical Activity, 9: 24, http://doi.org/10.1186/1479-5868-9-24

Deci, E.L., Ryan, R.M., Gagné, M., Leone, D.R., Usunov, J., \& Kornazheva, B.P. (2001). Need satisfaction, motivation, and well-being in the work organizations of a former eastern bloc country: a cross-cultural study of self-determination. Personality and Social Psychology Bulletin, 27(8), 930-942, http://doi. org/10.1177/0146167201278002

Deci, E.L., \& Ryan, R.M. (2000). Intrinsic and extrinsic motivations: classic definitions and new directions. Contemporary Educational Psychology 25, 54-67, http://doi.org/10.1006/ceps.1999.1020

Hamel, G. (2012). What matters now: how to win in a world of relentless change, ferocious competition, and unstoppable innovation. San Francisco CA: Jossey-Bass.

Gagné, M., Forest, J., Vansteenkiste, M., Crevier-Braud, L., \& van den Broeck, A. (2015). The multidimensional work motivation scale: validation evidence in seven languages and nine countries. European Journal of Work and Organizational Psychology, 24(2), 178-196, http://doi.org/10.1080/1359432X.2013.877892

Gagné, M., \& Deci, E.L. (2005). Self-determination and work motivation. Journal of Organizational Behaviour, 26(4), 331-362, http://doi.org/10.1002/job.322

Hajdukova, A., Klementova, J., \& Klementova J. jr. (2015). The job satisfaction as a regulator of the working behaviour. Procedia - Social and Behavioral Sciences 190, 471 - 476, http://doi.org/10.1016/j.sbspro.2015.05.028

Hernaus, T., \& Mikulić, J. (2013). Work characteristics and work performance of knowledge workers: what goes hand in hand? Faculty of Economics and Business Zagreb, Working Paper Series 13-09. Retrieved from: http://hrcak.srce.hr/136794

Holden, N., \& Vaiman, V. (2013). Talent management in Russia: not so much war for talent as wariness of talent. Critical Perspectives on International Business, 9(1/2), 129-146, http://doi.org/10.1057/978-1-13750606-1

Jaros, S. (2007). Mayer and Allen model of organizational commitment: measurement issues. The Icfai Journal of Organizational Behavior, VI(4), 7-25, http://doi. org/10.1017/jmo.2014.21

Jordan, G., Miglič, G., Todorović, I., \& Marič, M. (2017). Psychological empowerment, job satisfaction and organizational commitment among lecturers in higher education: comparison of six CEE Countries. Organizacija, 50(1), 17-32, http://doi.org/10.1515/orga2017-0004

Kanning, U.P., \& Hill, A. (2013). Validation of the organizational commitment questionnaire (OCQ) in six languages. Journal of Business and Media Psychology 4(2), 11-20. retrieved from www.journal-bmp.de

Kanfer, R., Frese, M., \& Johnson, R.E. (2017). Motivation related to work, a century of progress. Journal of Applied Psychology, (102)3, 338-355, http://doi. org/10.1037/apl0000133

Kanfer, R., Chen, G., \& Pritchard, R. (eds.) (2008a). Work motivation: past, present, and future. New York NY: Routledge.

Kanfer, R., Chen, G., \& Pritchard, R (2008b) The three C's of work motivation: content, context, and change. In Kanfer et al. (2008a), pp. 1-16.

Kanfer, R. (1990) Motivation theory and industrial and organizational psychology. In Dunnette, M.D. \& Hough, L.M. (dds.), Handbook of industrial and organizational psychology (2nd ed), Vol. 1, pp. 75-170). Palo Alto, CA: Consulting, Psychologists Press.

Kooij, D. T. A. M., de Lange, A. H., Jansen, P. G. W., Kanfer, R., \& Dikkers, J. S. E. (2011). Age and work-related motives: results of a meta-analysis. Journal of Organizational Behavior, 32(2), 197-225, http://doi. org/10.1002/job.665

Latham, G.P. (2012). Work motivation, history, theory, research, and practice. Thousans Oacks CA: Sage.

Lewandowski, P. (2017). The changing nature of jobs in Central and Eastern Europe. Bonn, IZA, IZA World of Labor 2017: 351. Retrieved from http://wol.iza.org/ articles/the-changing-nature-of-jobs-in-central-andeastern-europe/long

Matusiak M. \& Kleibrink A. eds. (2018). Supporting an innovation agenda for the Western Balkans, tools and methodologies. Luxembourg; Publications Office of the European Union.

Mercurio, Z.A. (2015). Affective commitment as a core essence of organizational commitment: an integrative literature review. Human Resource Development Review, 14(4), 389-414, http://doi. org/ $10.1177 \% 2 \mathrm{~F} 1534484315603612$

Meyer, J., \& Allen, N. (1997). Commitment in the Workplace: Theory, Research, and Application. Thousand Oaks CA, Sage Publications.

Morgan, J. (2014). The future of work. Hoboken NJ: Wiley.

Mullins, L.J. (2010). Management \& organisational behaviour. Harlow Essex: Pearson.

Nientied, P., \& Shutina, D. (2017). High performance work practices in Albania. Journal of Human Resource Management, $X X$ (2), 12-20. Retrieved from www. jhrm.eu/2017/10/12-high-performance-work-practices-in-albania/

Nientied, P., \& Karafili, E. (2016). Towards a pragmatic perspective on business innovation in Western Balkan 
countries: the case of Albania. International Journal of Business and Management, 11(3), 193-202, http://doi. org/10.5539/ijbm.v11n3p193

Pink, D. (2011). Drive: the surprising truth about what motivates us. New York NY: Riverheads Books.

Ployhart, R.E. (2008). The measurement and analysis of motivation. In: Kanfer, R., Chen, G., \& Pritchard, R. (eds.) (2008a), p. 18-61.

Poór, J., Engle, E.D., Szlávicz, A., Kerekes, K., Szabó, K., Kovács, I.E., \& Józsa, I. (eds.) (2015). Human resources management issues and challenges in foreign owned companies: Central and Eastern Europe (2011-2013). Komárno, Slovakia: Faculty of Economics, J. Selye University.

Prašnikar, J., Redek, T., \& Memai, F. (2012). Albania: the role of intangible capital in future growth. Ljubljana: Faculty of Economics. Retrieved from http://maksi2. ef.uni-lj.si/zaloznistvoslike/371/Albania cela.pdf

RCC (Regional Cooperation Council) (2017). Balkan Barometer 2017, Public opinion survey. Sarajevo, RCC. Retrieved from www.rcc.int/seeds/files/RCC_BalkanBarometer PublicOpinion 2017.pdf

Ryan, M.R., \& Deci, E.L. (2000). Self-determination theory and the facilitation of intrinsic motivation, social development, and well-being. American Psychologist 55(1), 68-78, http://doi.org/10.1037/0003066X.55.1.68

Schwab, K. (2018). Shaping the future of the fourth industrial revolution. London, Penguin.

Shoraj, D., \& Llaci, S. (2015). Motivation and its impact on organizational effectiveness in Albanian businesses. Sage Open, 5(2), 1-8, http://doi. org/10.1177\%2F2158244015582229

Solinger, O.M., Van Olffen, W., \& Roe, R.A. (2008). Beyond the three-component model of organizational commitment. Journal of Applied Psychology, 93(1), 70 - $83 \mathrm{http://doi.org/10.1037/0021-9010.93.1.70}$

Starnes, B.J., \& Truhon, S.A. (n.d.). A primer on organizational commitment. Milwaukee IL: American Society for Quality, The Human Development and Leadership Division. Retrieved from http://asqhdandl.org/uploads/3/4/6/3/34636479/commitment.pdf

Suma, S., \& Lesha, J. (2013). Job satisfaction and organizational commitment: the case of Shkodra municipality. European Scientific Journal 9(17), 41-51, http://doi. org/10.19044/esj.2013.v9n17p\%25p

Tremblay, M.A., Blanchard, C.M., Taylor, S., Pelletier,
L.G., \& Villeneuve. N. (2009). Work extrinsic and intrinsic motivation scale: its value for organizational psychology research. Canadian Journal of Behavioural Science, 41(4), 213-226, http://doi.org/10.1037/ a0018176

Vracic, A. (2018). The way back: brain drain and prosperity in the Western Balkans. London, European Council on Foreign Relations, ECFR/257. Retrieved from www.ecfr.eu/publications/summary/the way back brain drain and prosperity in the western balkans

WEF - World Economic Forum (2016). The future of jobs. Geneva: WEF.

World Bank (2018). Higher but fragile growth. Washington, World Bank Group, Western Balkans Regular Economic Report No. 14.

Zientara, P. (2014). Human resource management in emerging economies. New York NY: Routledge.

Zaccaro, S.J., Ely, K., \& Nelson, J. (2008). Leadership processes and work motivation. In: Kanfer, et al. (eds.) (2008a), p. 319-360.

Zhilla, E. (2013). Work motivation in the academe: the case of Albanian public universities. Journal of Educational and Social Research 3(1), 93-98, http://doi. org/10.5901/jesr.2013.v3n1p9

Peter Nientied, PhD, is affiliated to Polis University, Tirana, Albania, and to NCOI University of Applied Arts, Hilversum, the Netherlands, and works as consultant and researcher. He teaches management \& innovation, HR subjects and urban social topics, guides research projects and gives advisory services. His current management research focuses on HR and leadership and on innovation. His personal website is www.peternientied.nl, ORCID 0000-0002-4067-9826

Merita Toska, PhD, is economic development and finance expert at Co-PLAN, Institute for Habitat Development, Tirana, Albania. She teaches Business Planning and Operations Management at Polis University, Tirana. Prior joining Co-PLAN and Polis University, she worked as economist for the Bank of Albania. Current research is on regional economic development. Her personal site is www.universitetipolis. edu.al/sites/default/files/pdf/BIO/Merita Toska en.pdf, ORCID 0000-0003-3797-1057. 